Conference Paper

\title{
Communicating Anti Bullying Educational Messages For Elementary School Student Through Board Game Storyline
}

\author{
Widyasari*, Aditya Rahman Yani, Nia Wulandari, Eki Cahya Imani \\ Visual Communication Design, Faculty of Architecture and Design, Universitas Pembangunan Nasional \\ "Veteran" Jawa Timur, Indonesia
}

*Corresponding author:

E-mail:

widyasari.dkv@upnjatim.ac.id

\begin{abstract}
Bullying behavior in elementary school children is increasing daily, following the current development of the digital era. It has become one of the most important cases to be followed up on because it can negatively affect the children's morals and it can also hurt others. Therefore, as an effort to tackle bullying cases, it is necessary to deliver innovative anti-bullying educational messages to children at the elementary school level, in hopes that children will become more interested, and will be easier to absorb the educational messages. Innovative anti-bullying educational messages can be delivered through an interesting and fun storyline of the board game media. The steps used to construct this research are identifying the problem or phenomenon, primary and secondary data collection, and analyzing the primary and secondary data using the Questioning Method of $5 \mathrm{~W}+1 \mathrm{H}$ (What, Why, Who, Where, When, How ) to compile anti-bullying educational messages for elementary school children which are packaged attractively through the storyline of a board game. This study concludes that there was three rating weight of anti-bullying actions carried out by elementary school children, namely mild, moderate, and severe. Each rating weight of anti-bullying has five forms of bullying so that there are 15 forms of bullying in total. Each bullying act is then processed into a case study in the form of questions on the board game, with a question model that intentionally touches the empathy of elementary school children. Each question has three positive answer options with different levels of anti-bullying (levels 1,2, and 3). These levels of anti-bullying are the points that will be obtained by each player (level $1=1$ point, level $2=2$ points, level $3=3$ points). If the player gets a total of 15 points as minimum points, then the player is considered to have low anti-bullying action if the player gets a total of 15-30 points, then the player is considered to have moderate anti-bullying action, and if the player gets a total of 30-45 points, then players are considered to have high antibullying actions. These total points are the rewards on this board game.
\end{abstract}

Keywords: Board game storyline, elementary school children, board game, anti bullying education.

\section{Introduction}

Bullying behavior in elementary school children is increasing daily, following the current development of the digital era where children as young as the elementary school level can easily find television shows and examples of bullying behavior without appropriate guidance (Erika et al., 2017). Bullying cases for elementary school children are also increasingly often being found either in printed, electronic, and social media. In some cases, bullying which in itself is a form of deviant behavior has even led to a criminal level. On the other hand, bullying behavior has not been taken seriously either by teachers or parents. They think that bullying behavior is one of the

\section{How to cite:}

Krishanti, N. P. R. A., Zulfiana, D., \& Wikantyoso, B. (2021). Antimicrobial production by an actinomycetes isolated from the termite nest. $5^{\text {th }}$ International Seminar of Research Month 2020. NST Proceedings. pages 105-115. doi: $10.11594 /$ nstp.2021.0916 
common processes of child development, so that there is no need to follow-up and solve this problem of bullying behavior. The further impact is that bullying often occurs repeatedly both in the school environment and in the neighborhood. Bullying behavior among elementary school children is the most important case to be followed up because it can negatively affect the children's morals and can also hurt others (Jan \& Husain, 2015).

Therefore, as an effort to tackle bullying cases in elementary school children, it is necessary to deliver innovative anti-bullying educational messages to children so that children can be more interested and absorb the educational messages easier. Anti-bullying educational messages can be delivered through an interesting storyline on the board game media, where children will feel challenged to solve a problem through the storyline, become winners, and get rewards (Soefandi, 2015). Also, children are mostly very fond of games, play activities, interactivity, and fun things. These aspects can help the educational messages to sink into the children.

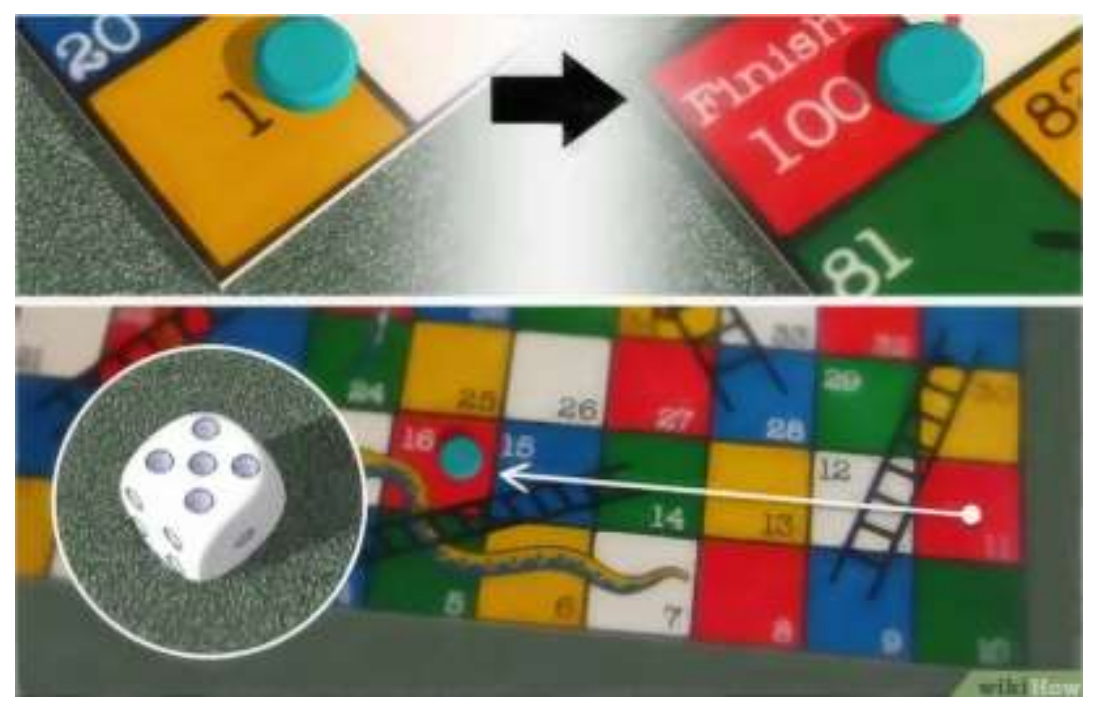

Figure 1. The example of the Snake \& Ladder board game (Source: id.wikihow.com)

Figure 1 is an example of a snake and ladder board game with the storyline is to determine who plays first by rolling the dice and seeing who gets the highest score. Each player rolls the dice again and move forward several squares according to the number that appears on the dice. Go up through the ladder while stopping at the ladder tile and descending through the snake while stopping at the ladder tile. Players can take additional turns if the number that appears on the dice is six. The player must stop right at the last square to become a winner

\section{Material and Methods}

The research method used in this research is a qualitative method with the following steps (Hossain, 2011):

1. Identifying a problem or phenomenon;

2. Primary and secondary data collection;

3. Analyzing primary and secondary data using the Questioning Method of $5 \mathrm{~W}+1 \mathrm{H}$ (What, Why, Who, Where, When, How) to compile anti-bullying educational messages to elementary school children which are delivered \& packaged attractively through the board game storyline. 


\section{Formulation of the research problem}

Researchers study the problem or phenomenon that is happening in society and is urgent to be resolved, to construct the mainframe of the research. The phenomena or problems that have been discovered are then observed and dissected carefully to find the truth within the existence of these phenomena or problems. Furthermore, the data that has been obtained will be more closely analyzed to be summed up as the problem formulation, so that an applicable solution can be found. The solution found through this study was to communicate the anti-bullying educational messages which were packaged attractively through a storyline on a board game to elementary school children as the output of this study.

\section{Data collection}

The data used in this study is collected in the form of primary data and secondary data collection. Primary data were collected through in-depth interviews, while secondary data were collected through literature studies.

\section{Primary data}

Primary data is the data collected directly from the source using various methods. The method used to collect primary data in this study is the qualitative method by conducting in-depth interviews.

- Depth Interview

An interview is a conversation conducted by two parties with a specific purpose, namely between the interviewer who asks the question and the interviewee who provides the answer to the question (Moleong, 2010). In this study, in-depth interviews were conducted with four different parties to obtain the necessary data.

The first interview was conducted with elementary school teachers in Surabaya as a source to obtain data related to bullying behavior that is often done by elementary school children, and to find out any antibullying education efforts that have been carried out thus far. The second interview was conducted with child psychologists to find out the solutions applied thus far to deal with bullying behavior performed by elementary school children based on the psychological point of view. The third interview was conducted with elementary school children in Surabaya to find out their level of interest in board games and how they behave towards their peers. The fourth interview was conducted with a board game media practitioner, namely one of the Indonesian board game creators, where the researchers acquire as much information as possible related to a board game with an interesting storyline to be played by elementary school children.

\section{Data analysis technique}

The qualitative data analysis in this study is conducted using the questioning method (namely the $5 \mathrm{~W}+1 \mathrm{H}$ analysis). The $5 \mathrm{~W}+1 \mathrm{H}$ analysis is an analysis method that uses the systematic set of questions consist of What, Why, Who, Where, When, and How to conclude anti-bullying educational messages for Elementary school level children who have packaged attractively through the storyline of a board game.

\section{Results and Discussion}

Primary data and secondary data that have been collected are then analyzed using the formulation of the $5 \mathrm{~W}+1 \mathrm{H}$ questions (What, When, Where, Why, Who, How) to conclude antibullying educational messages for elementary school children which are packaged attractively through the storyline of a board game. 


\section{What}

Table $1.5 \mathrm{~W}+1 \mathrm{H}$ analysis: what

\section{What forms of bullying are often carried out by elementary school children?}

According to the results of an interview with one of the teachers at a private elementary school in Surabaya, some of the bullying actions often carried out by students are teasing, making fun of their parents' names, sneering at friends who have new things, borrowing things without permission, returning things as they please, and not saying "thank you".

According to the results of interviews with two target audiences of students in private elementary schools and public elementary schools in Surabaya, some of the bullying acts that are often carried out by students are being nosy, making fun of their parents' names, hitting, and setting pranks.

According to the results of interviews with child psychologists, some of the bullying actions that are often carried out by students are mocking, excluding from groups, and being picky in choosing playmates

\section{Is anti-bullying education implemented in schools, especially at the elementary school level?}

According to the results of an interview with one of the teachers at a private elementary school in Surabaya, so far there have been positive activities that are often held in schools to support anti-bullying education. These activities are such as charity as character building to care for others, such as sharing meals, giving a donation to other fellow students who have been stricken with misfortune, lending items to each other, and so on. If there is bullying against students at school, the teacher provides positive message education verbally many times to the students.

According to the results of interviews with two target audiences of students in private elementary schools and public elementary schools in Surabaya, teachers usually give messages to students to share and help each other with their friends at school. If there are acts of bullying at school such as students quarreling or taunting each other, the teacher's attitude is to reprimand students for doing these actions, threaten to report to the principal, and give punishment for doing assignments outside the classroom.

\section{What innovative educational message delivery models have been used in schools?}

According to the results of an interview with one of the teachers at a private elementary school in Surabaya, the educative message delivery model that has been used in schools is storytelling, playing true story videos that can touch the empathy of students.

According to the results of interviews with two target audiences of students at private elementary schools and public elementary schools in Surabaya, teachers have taught using more interesting methods at schools, such as using collages and storytelling. 


\section{When}

Table 2. 5W+1H Analysis: When

When is the time this anti-bullying educational message most effectively conveyed to children?

According to the results of an interview with one of the teachers at a private elementary school in Surabaya and a child psychologist, the message of anti-bullying education is more effectively conveyed to elementary school children in the fourth grade to the sixth grade, because of their understanding of the environment is improving at that level.

\section{Where}

Table 3. $5 \mathrm{~W}+1 \mathrm{H}$ Analysis: Where

\section{Where can children receive anti-bullying educational messages?}

This anti-bullying educational message will be conveyed by the teacher to students while at school. The teacher will assist students in delivering anti-bullying educational messages so that there is no misperception of children in receiving bullying educational messages.

\section{Why}

Table. 4 5W+1H Analysis: Why

\section{Why raise anti-bullying educational messages?}

The number of bullying behaviors among elementary school children is increasing each day and is increasingly often being found in print, electronic, and social media. Moreover, violence act which in itself is a form of deviant behavior has led up to criminal acts. Bullying behavior among children at the elementary school level is the most important case to be followed up because it can negatively affect children's morals and can hurt others. So as an effort to overcome bullying cases, anti-bullying education is needed to be carried out for children at the level of bullying. Primary school.

According to the results of an interview with a teacher at a private elementary school in Surabaya, the school always tries to instill a positive attitude towards students at school, such as holding activities that support anti-bullying education in schools. Also, the teacher continues to provide anti-bullying educational messages verbally to students at school, such as reminding students to always be positive with friends.

\section{Who}

Table 5. 5W+1H Analysis: Who Who is the target audience for anti-bullying educational messages?

The target audience for the recipients of anti-bullying educational messages is children at the elementary school level in grades four to six because the level of their environmental understanding is much better at such stage. The target audience's social class is middle class and above, considering the target audience's parents' economy-level capable to afford board games. Geographically, the target audiences are Elementary students studying in Public and Private Elementary Schools located in the City of Surabaya. While psychographically, the targeted audiences are those that are interested in challenging 
games and require a problem-solving skill. Based on the behavioral aspect, the target audiences are those who enjoy learning while playing games.

\section{Anti-bullying educational messages}

After analyzing the data using the $5 \mathrm{~W}+1 \mathrm{H}$ formula, then the anti-bullying educational message as in Table-7 are being constructed with the following explanation:

1. The anti-bullying actions carried out by elementary school children are ranked into three different rating weight, namely mild, moderate, and heavy.

2. Each rating weight has five forms of bullying behavior which are often carried out by children at the elementary school level. So, there are 15 forms of bullying behavior in total.

3. Each form of bullying is then processed into a case study in the form of questions on the board game with a question model that touches the empathy of elementary school children. 15 questions in total must be answered by each player.

4. Each question has three positive answer options in different anti-bullying levels (levels 1,2 , and 3). The anti-bullying level marks the point that each player will get with every question (level $1=1$ point, level $2=2$ points, level $3=3$ points).

5. All points obtained from 15 questions will be summed as the final point at the end of the game. The maximum point that can be obtained by a player is 15 question $\times 3$ points $=45$ points, and the minimum point that a player can obtain is 15 question $\times 1$ points $=$ 15 points

6. If a player gets a total of 15 points as minimum points, then the player is considered to have low anti-bullying action if the player gets a total of 15-30 points, then the player is considered to have moderate anti-bullying action, and if the player gets a total of 30 45 points, then the player is considered to have high anti-bullying action. These total points are rewarded on the board game.

Table 7. The Copywrite list of anti-bullying educational messages packaged through the board game storyline

\begin{tabular}{|c|c|c|c|c|c|}
\hline Numb. & $\begin{array}{l}\text { Bullying } \\
\text { Act Rat- } \\
\text { ing }\end{array}$ & $\begin{array}{l}\text { Bullying } \\
\text { Form } \\
\text { (According to } \\
\text { Research) }\end{array}$ & $\begin{array}{c}\text { Questions } \\
\text { Draft } \\
\text { (Bullying Act } \\
\text { Case Studies) }\end{array}$ & $\begin{array}{l}\text { Answer Options Draft } \\
\text { (Anti Bullying Education) }\end{array}$ & $\begin{array}{l}\text { Answer } \\
\text { Points } \\
\text { (Anti Bul- } \\
\text { lying } \\
\text { Level) }\end{array}$ \\
\hline \multirow[t]{2}{*}{1.} & \multirow[t]{2}{*}{ Mild } & \multirow[t]{2}{*}{$\begin{array}{l}\text { Picky when } \\
\text { choosing a } \\
\text { playmate }\end{array}$} & \multirow[t]{2}{*}{$\begin{array}{l}\text { Your friend is } \\
\text { always alone } \\
\text { and sad in } \\
\text { class, no one } \\
\text { wants to play } \\
\text { with him be- } \\
\text { cause his uni- } \\
\text { form is worn. } \\
\text { What would } \\
\text { you do? }\end{array}$} & $\begin{array}{l}\text { I will invite my friends to } \\
\text { play, but I am afraid that } \\
\text { my other friends will also } \\
\text { avoid me later. } \\
\text { I will invite my friends to } \\
\text { play regardless of } \\
\text { whether I get avoided by } \\
\text { the others or not. }\end{array}$ & 2 \\
\hline & & & & $\begin{array}{l}\text { I will invite my friends to } \\
\text { play and invite other }\end{array}$ & 3 \\
\hline
\end{tabular}




\begin{tabular}{|c|c|c|c|c|c|}
\hline & & & & $\begin{array}{l}\text { friends to want to play } \\
\text { with him. }\end{array}$ & \\
\hline \multirow[t]{4}{*}{2.} & Mild & $\begin{array}{l}\text { Make friends } \\
\text { feel inferior }\end{array}$ & $\begin{array}{l}\text { During class, } \\
\text { the teacher }\end{array}$ & $\begin{array}{l}\text { I will ask the teacher to } \\
\text { convince my friend. }\end{array}$ & 1 \\
\hline & & & $\begin{array}{l}\text { asks your } \\
\text { friend to come } \\
\text { to the front of } \\
\text { the class, but } \\
\text { your friend is }\end{array}$ & $\begin{array}{l}\text { I will convince my friend } \\
\text { and encourage him to } \\
\text { come to the front of the } \\
\text { class. }\end{array}$ & 2 \\
\hline & & & $\begin{array}{l}\text { not confident } \\
\text { because he is } \\
\text { afraid of being } \\
\text { teased by your } \\
\text { classmates. }\end{array}$ & $\begin{array}{l}\text { I will reassure my friend, } \\
\text { encourage him, and help } \\
\text { him if he gets into trouble. }\end{array}$ & 3 \\
\hline & & & $\begin{array}{l}\text { What would } \\
\text { you do? }\end{array}$ & & \\
\hline \multirow[t]{4}{*}{3.} & Mild & $\begin{array}{l}\text { Taunts and } \\
\text { make friends } \\
\text { feel inferior }\end{array}$ & $\begin{array}{l}\text { In your school, } \\
\text { some friends } \\
\text { feel sad and } \\
\text { not confident }\end{array}$ & $\begin{array}{l}\text { I will tell my friends to } \\
\text { stop making fun of him, } \\
\text { but I am afraid that they } \\
\text { will stay away from me. }\end{array}$ & 1 \\
\hline & & & $\begin{array}{l}\text { because other } \\
\text { friends call him } \\
\text { fat. }\end{array}$ & $\begin{array}{l}\text { I will tell my friend to al- } \\
\text { ways be confident and ig- } \\
\text { nore the teasing of other }\end{array}$ & 2 \\
\hline & & & What would & friends. & \\
\hline & & & you do? & $\begin{array}{l}\text { I will tell my friends to al- } \\
\text { ways be confident and tell } \\
\text { their friends to stop mak- } \\
\text { ing fun of them. }\end{array}$ & 3 \\
\hline \multirow[t]{4}{*}{4.} & Mild & $\begin{array}{l}\text { Teasing other } \\
\text { friends }\end{array}$ & $\begin{array}{l}\text { There is one } \\
\text { friend who is } \\
\text { always annoy- }\end{array}$ & $\begin{array}{l}\text { I will tell the teacher if } \\
\text { there are friends who are } \\
\text { nosy in class. }\end{array}$ & 1 \\
\hline & & & $\begin{array}{l}\text { ingly teasing } \\
\text { the others in } \\
\text { the class, so } \\
\text { many friends }\end{array}$ & $\begin{array}{l}\text { I will reprimand my nosy } \\
\text { friend and invite him to } \\
\text { play with me }\end{array}$ & 2 \\
\hline & & & $\begin{array}{l}\text { keep them- } \\
\text { selves away } \\
\text { from him. }\end{array}$ & $\begin{array}{l}\text { I will reprimand my nosy } \\
\text { friend and invite the other } \\
\text { classmates not to avoid }\end{array}$ & 3 \\
\hline & & & $\begin{array}{l}\text { What would } \\
\text { you do? }\end{array}$ & $\begin{array}{l}\text { him and play together } \\
\text { with him because he is } \\
\text { also our friend. }\end{array}$ & \\
\hline
\end{tabular}


5. $\quad$ Mild

Ridiculing
friends

Every time the

I will alert friends who

teacher gives

mock, but I am afraid that

an assignment

I will also become the

about telling

next target of their taunts.

the family and

I will remind my friends

mentions the

that we should not make

names of par-

fun of our parents' names.

ents, friends

often make the

I will remind my friends

names of the

parents as ma-

terial for ridi-

cule.

that we should not mock

and have to respect those

who are older than us

even though they are not

our parents.

What would

you do?

6. Moderate Showing off

There is one of

I will remind my friend your friends

not to show off anymore,

friends

who like to

but I am afraid that he

show off with

will be offended and

new things to

turned hostile towards

the point of

me.

making friends

I will remind my friends

jealous and sad

because they

can't have that

item.

I will remind my friends

not to show off anymore,

to share, and willingly

What would lend their things to other

you do?

friends.

7. Moderate

Lying and
blaming
friends

You see two of

I will tell the teacher what your friends happened, but I am afraid

fighting over that after that he will turn stationery until the teacher comes to intervene. One of your friends doesn't want to against me.

be blamed and doesn't speak honestly to the I will reprimand my teacher. friend for speaking honestly to the teacher after that incident.

I will tell the teacher what 3 happened. 


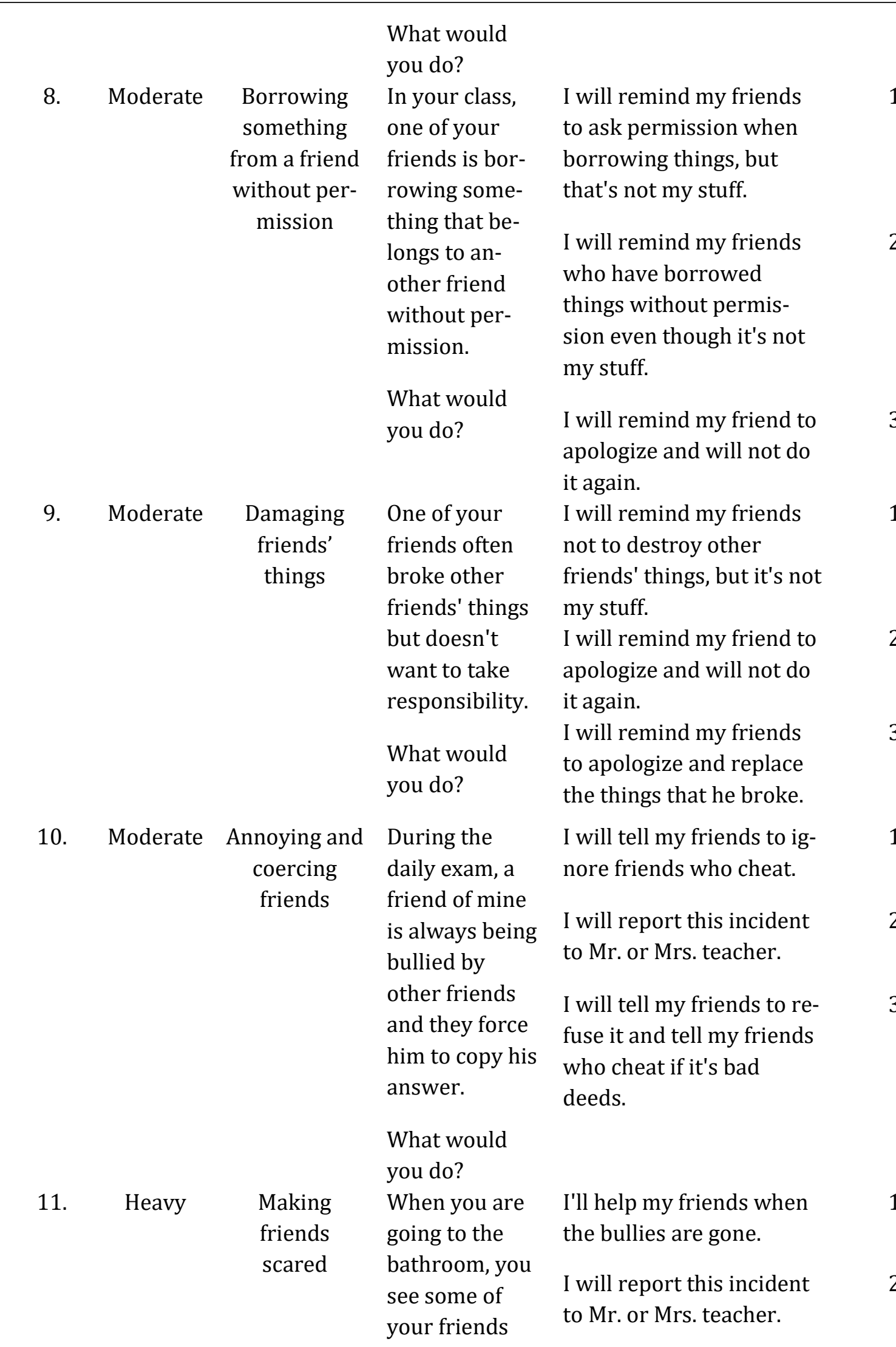

To be continued... 
lock the bath-

room door of other friends who are in it until they are scared.

What would you do?

12. Heavy Pull a prank Your friends on a friend are crying, their uniforms are soaked with water because they were pranked by some classmates.

What would you do? 13. Heavy Hurting a
friend

14. Heavy

Your friend's hand hurts a lot because another friend hit him for no reason.

What would you do?
I will stop them and reprimand them.

$$
\text { the uniform }
$$

I will help my friend and report this incident to $\mathrm{Mr}$. or Mrs. teacher.

I will help my friends and reprimand the friends who pull a prank on him to apologize and not to repeat it.

I will let off the friend who hit and ask my friend not to get back because it will hurt.

I will remind the hitting friend to apologize to my friend for hurting.

I will remind the friend who hit to apologize and report this incident to the teacher or teacher.

I will help my friend to be

tended in the infirmary was in pain when he fell and his knee was bleeding reprimand the friends who had pushed them.

To be continued... 


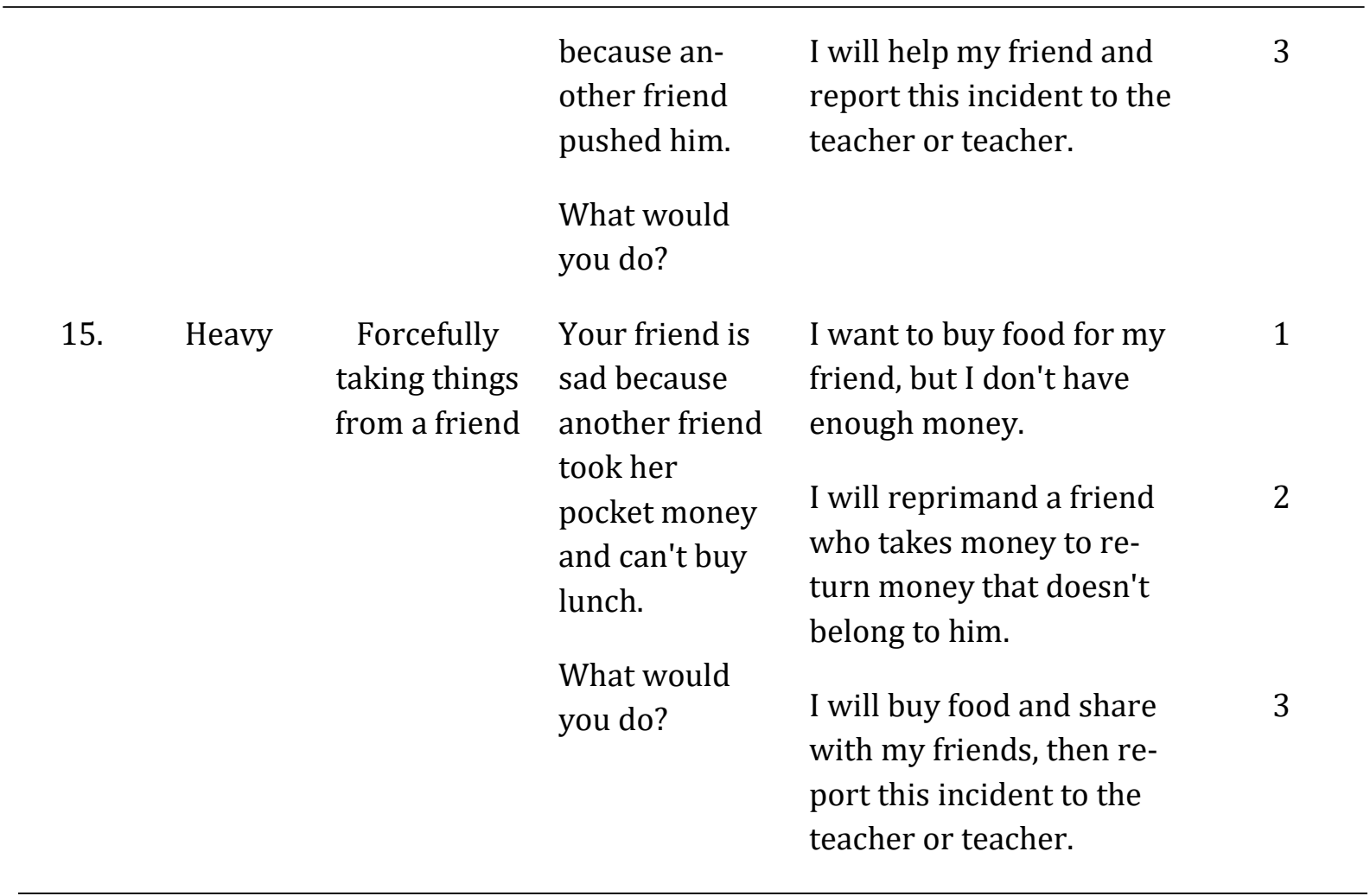

\section{Conclusion}

The conclusion in this study is that the anti-bullying actions carried out by elementary school children are ranked into three different rating weights, namely mild, moderate, and heavy. Each rating weight of anti-bullying action has five forms of bullying which are often carried out by elementary school children, so there are 15 forms of bullying in total. Each form of bullying is then processed into a case study in the form of questions on the board game, with a question model that touches the empathy of elementary school children. Each question has three positive answer options in different anti-bullying levels (levels 1,2, and 3). The anti-bullying level marks the point that each player will get (level $1=1$ point, level $2=2$ points, level $3=3$ points). These points are rewarded in the board game. If the player gets a total of 15 points as minimum points, then the player is considered to have low anti-bullying action if the player gets a total of $15-30$ points, then the player is considered to have moderate anti-bullying action, and if the player gets a total of 30 45 points, then players are considered to have high anti-bullying actions.

\section{Acknowledgment}

We would like to thank the Institute for Research and Community Service (LPPM), the Universitas Pembangunan Nasional "Veteran" Jawa Timur for providing funding for this activity. We also express our gratitude to all parties who helped this activity to the end.

\section{References}

Erika, K.A., Pertiwi, D. A., \& Seniwati, T. (2017). Bullying behavior of adolescents based on gender, gang and family. Jurnal Ners, 12(1), 126-132.

Hossain, D. M. (2011). Qualitative research process. Postmodern Opening, 7(7),143-156.

Jan, M.A., \& Husain, S. (2015). Bullying in elementary schools: Its causes and effects on students. Journal of Education and Practice, 6(19), 43-56.

Moleong, L.J. (2010). Metodologi penelitian kualitatif. Bandung. PT. Remaja Rosdakarya.

Soefandi, I. (2015). Strategi mengembangkan potensi kecerdasan anak. Jakarta: Bee Media Indonesia 